Keywords: immune checkpoint; cytokines; radiation; head and neck cancer; PD-1; tumour antigens; anti-tumour immunity; abscopal

\title{
Definitive chemoradiation alters the immunologic landscape and immune checkpoints in head and neck cancer
}

\author{
Vishwajith Sridharan ${ }^{1,2}$, Danielle N Margalit ${ }^{1}$, Stephanie A Lynch ${ }^{1}$, Mariano Severgnini ${ }^{3}$, Jun Zhou ${ }^{3}$, \\ Nicole G Chau ${ }^{4}$, Guilherme Rabinowits ${ }^{4}$, Jochen H Lorch ${ }^{4}$, Peter S Hammerman ${ }^{4}$, F Stephen Hodi ${ }^{3,4}$, \\ Robert I Haddad ${ }^{4}$, Roy B Tishler ${ }^{1}$ and Jonathan D Schoenfeld ${ }^{\star}, 1$ \\ ${ }^{1}$ Department of Radiation Oncology, Brigham and Women's Hospital/Dana-Farber Cancer Center, Boston, MA, USA; ${ }^{2}$ Harvard- \\ MIT Division of Health Sciences and Technology, Harvard Medical School, Boston, MA, USA; ${ }^{3}$ Center for Immuno-oncology, \\ Dana-Farber Cancer Institute, Boston, MA, USA and ${ }^{4}$ Department of Medical Oncology, Brigham and Women's Hospital/Dana- \\ Farber Cancer Center, Boston, MA, USA
}

Background: Preclinical and clinical studies suggest potential synergy between high dose per fraction focal radiation and immunotherapy. However, conventionally fractionated radiation regimens in combination with concurrent chemotherapy are more commonly administered to patients as definitive treatment and may have both immune-stimulating and -suppressive effects.

Methods: We prospectively collected longitudinal samples from head and neck squamous cell carcinoma patients receiving definitive radiation therapy. We quantified changes in populations of circulating immune cells and chemokines CXCL9, 10, and 16. Analyses of humoral and cellular immune responses were conducted in select patients via proteomic analysis and T-cell receptor sequencing.

Results: Treatment not only increased circulating CD-8 + T-effector cells, but also myeloid-derived suppressor cells, regulatory T cells, and checkpoint receptor-expressing T cells, particularly PD-1 + T cells. Significant decreases in CXCL10 and increases in CXLC16 were noted. Treatment also increased the percentage of unique and dominant TCR clones, and increased humoral responses as measured by proteomic array.

Conclusions: Our results suggest that fractionated chemoradiation leads to quantifiable effects in circulating immune mediators, including a balance of stimulatory and suppressive mechanisms. These results suggest future combinations with immune checkpoint blockade.

Immune checkpoint blockade, and specifically blockade of the inhibitory programmed cell death protein 1 (PD-1) receptor, has a proven role in the treatment of melanoma, renal cell carcinoma, and non-small cell lung cancer, and preliminary studies have demonstrated efficacy in a variety of other tumour types including squamous cell carcinoma of the head and neck (SCCHN) (Hodi et al, 2010; Kantoff et al, 2010; Robert et al, 2011; Brahmer et al, 2012; Topalian et al, 2012; Segal et al, 2014; Seiwert et al, 2014; Borghaei et al, 2015; Motzer et al, 2015; Schoenfeld, 2015). However, response rates to single agent checkpoint blockade are generally limited. Consequently, combined treatment strategies are needed to increase the percentage of responding patients. One potential combination is to pair immune checkpoint blockade with standard therapies such as chemotherapy and radiation, as these cytotoxic therapies have demonstrated synergy with immune checkpoint blockade in multiple preclinical models (Formenti and Demaria, 2013; Wolchok and Chan, 2014; Deng et al, 2014a).

Both chemotherapy and radiation have both stimulatory as well as inhibitory effects on anti-tumour immunity as shown in animal studies (Levy et al, 2013; de la Cruz-Merino et al, 2014). More

*Correspondence: Dr JD Schoenfeld; E-mail: jdschoenfeld@partners.org

Received 28 February 2016; revised 1 May 2016; accepted 9 May 2016; published online 5 July 2016

(c) 2016 Cancer Research UK. All rights reserved 0007-0920/16 
limited data in human patients have suggested targeted radiation delivered in a relatively limited number of fractions (generally five or fewer) can have local immunologic effects and also impact circulating immunologic cytokines, regulatory $\mathrm{T}$ cells and myeloidderived suppressor cells (MDSCs) (Sridharan and Schoenfeld, 2015). Intriguing case reports have suggested that hypofractionated radiation may potentiate response in melanoma and non-small cell lung cancer patients treated with cytotoxic T-lymphocyte antigen 4 (CTLA-4) blockade and lead to abscopal responses outside of the radiation treatment field (Postow et al, 2012; Golden et al, 2013). Of note, examination of the peripheral blood in a melanoma patient who demonstrated an abscopal response revealed increases in activated T cells, decreases in MDSCs and elevated titres of antitumour antibodies (Postow et al, 2012). However, in general, the mechanisms by which radiation may impact systemic immunity and synergise with checkpoint blockade in human patients are poorly defined. In particular, less is known about the immunologic effects of conventionally fractionated chemoradiation (less than 3 Gy per fraction) delivered over a period of 5-7 weeks in the absence of prior chemotherapy or surgery; thus, settings where the intact tumour and disease in the tumour draining lymph nodes may be partially immunosuppresive. Fractionated radiation with or without chemotherapy is commonly used in the definitive management of patients with SCCHN as well as patients with locally advanced squamous cell carcinomas of the lung, cervix, and anus, and prostate adenocarcinoma. These fractionated regimens are also more difficult to recapitulate in animal models.

SCCHN affects more than 500000 people across the world annually, and has been increasing in frequency in the United States since 2005 as a result of cancers mediated by previous infection with the human papilloma virus (HPV) (Jemal et al, 2013). Radiation with or without chemotherapy is frequently used as definitive treatment for head and neck cancers, particularly for locally advanced tumours in the nasopharynx, larynx and oropharynx. SCCHN is also a promising target for immunotherapy, given a combination of viral and carcinogen-induced antigens, expression of immune checkpoint ligands such as PD-1 ligand (PD-L1), and preliminary reports of the efficacy of PD-1 inhibition in patients with metastatic disease (Schoenfeld, 2015). Thus, the combination of standard chemoradiation with immunotherapy in the treatment of SCCHN is of great interest. In order to help guide future studies integrating chemoradiation and immunotherapy, we performed a prospective study evaluating systemic immune effects of definitive chemoradiation in SCCHN patients. Here, we attempt to define immunologic mechanisms that may contribute to the efficacy and limitations of standard chemotherapy and radiation and form the basis of synergy with anti-tumour immunotherapy.

\section{MATERIALS AND METHODS}

Study design and patient population. We prospectively enrolled patients receiving definitive intent radiation to the head and neck region with or without chemotherapy on an Institutional Review Board-approved protocol to collect peripheral blood samples longitudinally during the course of treatment. In order to be eligible, all patients needed to have gross disease above the clavicles that was being targeted by radiation treatment and were also without evidence of distant metastatic disease. All patients provided informed consent.

A pilot study of 10-15 patients with heterogeneous tumour histologies including SCCHN was conducted to examine general effects of chemoradiation on serum biomarkers (cytokines, chemokines and immune cell subsets). This pilot study suggested potential changes in CXCL9, CXCL10 and CXCL16 over the course of treatment but not in TNF $\alpha$, IL1, IL10, IFN $\alpha 2, \operatorname{IFN} \beta$, or TGF $\beta$. Our pilot study also indicated potential effects on $\mathrm{CD} 4+$ and
CD8 + T-cell subsets over the course of chemoradiation, but no consistent effect on natural killer or natural killer $\mathrm{T}$ cells as a percentage of peripheral blood mononuclear cells (PBMCs). To investigate further, we specifically examined CXCL9, 10 and 16 as well as circulating immune T-cell subsets in a more homogenous prospective cohort of consecutive SCCHN patients at the beginning and end of chemoradiation.

We collected baseline information from these patients including demographics, histology, disease site, as well as tumour and nodal stage. We determined tumour association with HPV, using both in situ hybridisation for high-risk HPV types (16 and 18), and immunohistochemistry for the p16 protein.

All patients were prescribed a 7-week course of curative-intent radiation with or without chemotherapy. All patients received radiation that was graphically planned, and with the exception of one early stage larynx cancer patient who received conformal radiation, all patients were treated to the primary site and bilateral neck with intensity-modulated radiation therapy (RT) to maximise normal tissue sparing. Radiation was delivered daily Monday to Friday; all patients were evaluated at least once weekly by the treating radiation oncologist or more often if clinically warranted. Peripheral blood samples were obtained in phlebotomy just before the beginning and end of the 7 weeks of therapy.

Following the completion of treatment, all patients were followed regularly in multidisciplinary head and neck clinic. Restaging positron emission tomography/computed tomography and computed tomography of the head and neck was performed approximately 3 months after treatment or earlier if clinically indicated. Neck dissection was performed if there was suspicion for residual disease. We abstracted treatment details and information about clinical course from the medical record.

Flow cytometry. We isolated PBMCs via centrifugation $(1500 \mathrm{~g}, 20 \mathrm{~min})$, and stored the PBMCs in freezing media $\left(10 \%\right.$ FBS RPMI $+10 \%$ DMSO) at $-80{ }^{\circ} \mathrm{C}$ on the same day of the blood draw. Flow cytometry was performed to quantify activated/cytotoxic $\mathrm{T}$ cells (CD3-PC7 +, CD4-FITC+/CD8$\mathrm{APC}+, \mathrm{CD} 69-\mathrm{PE}+$ ), regulatory $\mathrm{T}$ cells or T-regs (CD4-FITC +, $\mathrm{CD} 25-\mathrm{PE}+, \mathrm{CD} 127-\mathrm{APC}-\mathrm{low}), \mathrm{T}$ cells expressing immune checkpoint receptors (CD4-FITC $+/ \mathrm{CD} 8-\mathrm{APC}+$, lymphocyte activation gene-3 or LAG3-Per710 + / T-cell immunoglobulin and mucin protein-3 or TIM3 Bv421 + /PD1-PE + ), and MDSCs $(\mathrm{CD} 14-\mathrm{APC}+$, HLA-DR PC7 - ) via established protocols. All antibodies were obtained from eBioscience (San Diego, CA, USA) except for CD8 APC (Miltenyi Biotec Inc, San Diego, CA, USA) and TIM3 Bv421 (Biolegend Inc, San Diego, CA, USA). FlowJo (Ashland, OR, USA) was used for analysis.

Cytokine assays. We isolated serum from blood samples using centrifugation $\left(3000 \mathrm{~g}, 10 \mathrm{~min}, 4^{\circ} \mathrm{C}\right)$ and then stored these samples at $-80^{\circ} \mathrm{C}$. CXCL9, 10 and 16 levels in serum were measured using the Bio-Plex Pro Human Cytokine Factor Assays (Bio-Rad Laboratories Inc, Hercules, CA, USA). Soluble IL2R levels were assessed using the Human IL-2R ELISA Kit (Thermo Fisher Scientific, Carlsbad, CA, USA) and sPD-L1 levels were assessed using the Human B7-H1 DuoSet ELISA (R\&D Systems, Minneapolis, MN, USA). All samples were tested in duplicate as experimental repeats against a standard curve of purified protein according to the manufacturer's protocol. Fluorescence intensity was measured via the Bio-Plex MAGPIX Multiplex Reader (BioRad Laboratories Inc).

Seromics. Proteomic analyses were performed with isolated patient serum using ProtoArray Immune Response Biomarker Profiling (ThermoFisher Scientific) using the manufacturer's protocols to detect the presence of antibodies directed against potential tumour-antigens pre- and post-RT. Candidate antibodies were considered to be significantly increased if signal intensity was 
$>3000$ relative fluorescence units, the signal-to-noise ratio was $>1.5$, and the fold change post-RT to pre-RT was $>2$. In addition, antibodies with relative fluorescence units $>65000$, which approached the upper boundary of the dynamic range as reported by the manufacturer, were considered to have the greatest interaction with candidate antigens.

T-cell receptor (TCR) sequencing. Multiplex PCR and highthroughput deep sequencing of T-receptor genes ((TCRB/IGH/ IGKL/TCRAD/TCRG) CDR3) were performed from selected patient PBMC DNA using the immunoSEQ assay (Adaptive Biotechnologies, Seattle, WA, USA) using the manufacturer's protocols. Data analysis was performed via the immunoSEQ Analyzer online platform (Adaptive Biotechnologies) to identify top T-cell clones and changes in gene frequency and clonality preand post-RT.

Statistical methods. Correlations between cytokine, immune subset, soluble marker levels and tumour and treatment parameters including sex, age, site of primary disease, HPV status, nodal involvement and smoking status were evaluated using the $\chi^{2}$ test. We compared changes in cytokine and immune subpopulation levels at the beginning and end of therapy using non-parametric Wilcoxon signed rank tests. Two-sided $P$-values $<0.05$ were considered statistically significant. All statistical analyses were computed using GraphPad Prism (GraphPad Software Inc, La Jolla, CA, USA), STATA 14.0 (StataCorp, College Station, TX, USA), or JMP Pro12 (SAS Institute Inc, Cary, NC, USA).

\section{RESULTS}

Patient characteristics and treatment parameters. We enrolled 20 consecutive patients and assayed blood samples for cytokines and T-cell subsets. Baseline patient characteristics are displayed in Table 1 . The median age of patients was 59 years (IQR 52.5-65). The majority of patients were male $(90 \%)$ with locally advanced HPV-associated disease. Eleven (55\%) had smoking history of greater than 10 pack-years. Patients received a median $70 \mathrm{~Gy}$ for disease in the oropharynx $(n=16,80 \%)$, nasopharynx $(n=2$, $10 \%)$, larynx $(n=1,5 \%)$, or oral cavity $(n=1,5 \%)$. Only one patient received less than this dose (64Gy) owing to medical co-morbidities. Eight patients $(40 \%)$ received concurrent bolus cisplatin at $100 \mathrm{mg} \mathrm{m}^{-2}$ every 3 weeks, seven (35\%) received concurrent weekly cisplatin $\left(30-40 \mathrm{mg} \mathrm{m}^{-2}\right)$ chemotherapy, two (10\%) received concurrent weekly carboplatin (AUC 1.5-2.0)paclitaxel $\left(30-45 \mathrm{mg} \mathrm{m}^{-2}\right.$ ), and three patients were treated with radiation alone. Median follow-up time for all patients was 14 months (range 5-23 months); there have been no pathologically proven local or distant failures to date.

Changes in serum cytokines and immune populations. There were no statistically significant associations between pre-treatment cytokine concentrations or proportions of CD4 , CD8 + T-cell subsets, regulatory $\mathrm{T}$ cells, or MDSCs with baseline patient characteristics, including smoking status. We also compared baseline cytokine levels with those found in serum from healthy controls. Median levels of CXCL9, 10, and 16 in controls is $135 \mathrm{pg} \mathrm{ml}^{-1}, 3 \mathrm{pg} \mathrm{ml}^{-1}$ (below the range of detection), and $231 \mathrm{pg} \mathrm{ml}^{-1}$ compared with baseline levels in our patients of $97.9 \mathrm{pg} \mathrm{ml}^{-1}, 54 \mathrm{pg} \mathrm{ml}^{-1}$, and $195 \mathrm{pg} \mathrm{ml}^{-1}$, respectively. The differences between CXCL9 $(P=0.32)$ and CXCL16 $(P=0.13)$ were not significant; however, the levels of CXCL10 were significantly higher in cancer patients at baseline as compared with controls $(P<0.0001)$.

We compared initial levels of cytokines and immune populations with those present in the final week of treatment. Treatment decreased concentrations of circulating CXCL10 $(P=0.001)$ and
Table 1. Patient characteristics

\begin{tabular}{|c|c|c|}
\hline Parameter & $\mathbf{n}$ & $\%$ \\
\hline Median age, IQR & 59 & \\
\hline \multicolumn{3}{|l|}{ Sex } \\
\hline Female & 2 & 10 \\
\hline Male & 18 & 90 \\
\hline \multicolumn{3}{|l|}{ Site } \\
\hline Base of tongue & 12 & 60 \\
\hline Tonsil & 4 & 20 \\
\hline Supraglottic larynx & 1 & 5 \\
\hline Nasopharynx & 2 & 10 \\
\hline Oral cavity & 1 & 5 \\
\hline \multicolumn{3}{|l|}{ HPV status } \\
\hline Positive & 16 & 80 \\
\hline Negative & 2 & 10 \\
\hline Not applicable/Unknown & 2 & 10 \\
\hline \multicolumn{3}{|l|}{ Smoking } \\
\hline$\leqslant 10$ pack-years & 11 & 55 \\
\hline$>10$ pack-years & 9 & 45 \\
\hline \multicolumn{3}{|l|}{ Concurrent chemotherapy } \\
\hline Bolus cisplatin & 8 & 40 \\
\hline Weekly cisplatin & 7 & 35 \\
\hline Carboplatin-Taxol & 2 & 10 \\
\hline No chemotherapy & 3 & 15 \\
\hline Median radiation dose (Gy), IQR & 70 & $70-70$ \\
\hline \multicolumn{3}{|l|}{ T-stage } \\
\hline $\mathrm{T} 1$ & 8 & 40 \\
\hline T2 & 7 & 35 \\
\hline T3 & 4 & 20 \\
\hline T4 & 1 & 5 \\
\hline \multicolumn{3}{|l|}{$\mathrm{N}$-stage } \\
\hline No & 4 & 20 \\
\hline N1 & 3 & 15 \\
\hline N2a & 2 & 10 \\
\hline $\mathrm{N} 2 \mathrm{~b}$ & 9 & 45 \\
\hline $\mathrm{N} 2 \mathrm{c}$ & 2 & 10 \\
\hline \multicolumn{3}{|l|}{ Stage } \\
\hline 1 & 2 & 10 \\
\hline$\|$ & 2 & 10 \\
\hline III & 2 & 10 \\
\hline IV & 14 & 70 \\
\hline
\end{tabular}

increased CXCL16 $(P=0.01)$, but did not affect CXCL9 $(P=0.57)$; Figure 1, Supplementary Figure 3. As expected, absolute lymphocyte counts decreased as a result of systemic chemotherapy, with 13 patients who received chemotherapy developing absolute lymphopenia $\left(<3.8 \times 10^{9}\right.$ cells per litre $)$ by the end of treatment time point. Patients also demonstrated a relative increase in the ratio of $\mathrm{CD} 8+\mathrm{T}$ cells as compared with $\mathrm{CD} 4+\mathrm{T}$ cells, but the percentages of $\mathrm{CD} 4+$ and $\mathrm{CD} 8+$ of all $\mathrm{CD} 3+\mathrm{T}$ cells did not change significantly $(P=0.09$ for $\mathrm{CD} 4+$ and $P=0.06$ for $\mathrm{CD} 8+)$. However, closer inspection indicated that there were significant changes in specific effector and immunosuppressive immune subsets over the course of treatment (Figure 2A and B).

Circulating CD8 + T-effector-cell proportions generally increased as a proportion of all CD8 + cells ( 15 of 20 patients, $P=0.02)$, but so did $\mathrm{CD} 4+$ regulatory $\mathrm{T}$ cells (17 of 20 patients, $P=0.01$ ) and MDSCs (14 of 20 patients, $P=0.03$ ) as a percentage of PBMCs.

Gating by total CD $4+\mathrm{T}$ cells and examining T cells expressing checkpoint receptors, increases were seen in CD4 + LAG3 + (16 of 20 patients, $P=0.02$ ), CD $4+$ TIM3 + (16 of 20 patients, $P=0.02)$, and $\mathrm{CD} 4+\mathrm{PD} 1+(16$ of 20 patients, $P=0.001)$ expressing cells. Similarly, evaluating CD8 $+\mathrm{T}$ cells, all three checkpoint receptor bearing cell populations increased following treatment: $\mathrm{CD} 8+\mathrm{LAG} 3+(15$ of 20 patients, $P=0.03), \mathrm{CD} 8+$ 


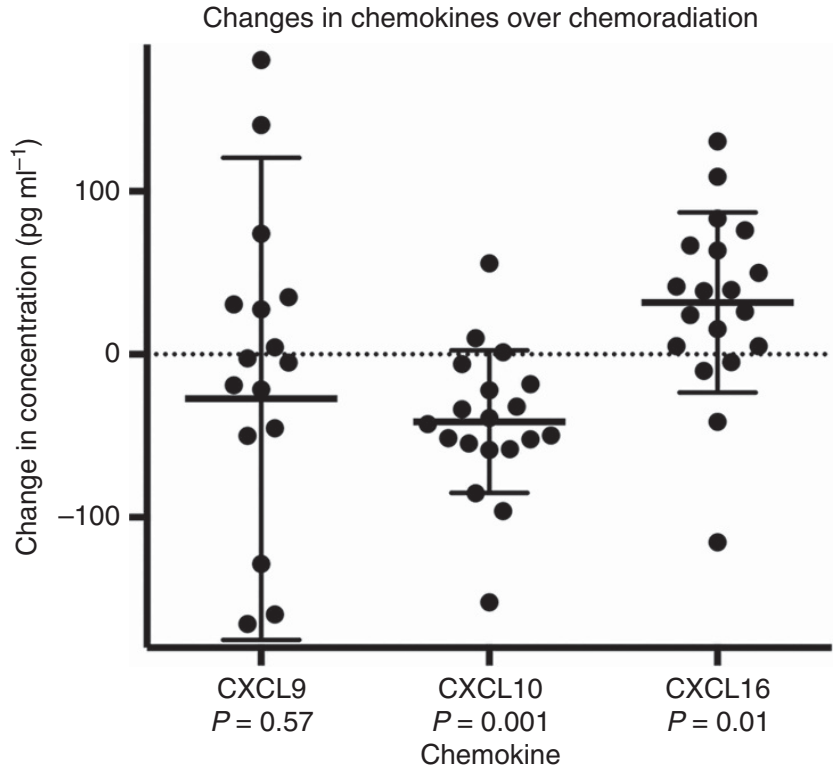

Figure 1. Changes in chemokine concentration over the course of 7 weeks of definitive chemoradiation to the head and neck region.

TIM3 $+(16$ of 20 patients, $P=0.02), \mathrm{CD} 8+\mathrm{PD} 1+(16$ of 20 patients, $P=0.01)$. Of particular note were the increases in $\mathrm{CD} 4+/ \mathrm{CD} 8+\mathrm{PD} 1+$-expressing cells (Figure 2C), which demonstrated relative increases over $200 \%$, and absolute increases of nearly $10 \%$ of overall CD $4+$ or CD $8+$ populations in selected patients. There were no statistically significant associations between these observed changes in T-cell populations and clinical factors such as history of tobacco use.

Given the pronounced increases in PD-1-expressing T cells, we also examined levels of circulating soluble PD-L1 ligand, which has been demonstrated in multiple myeloma, non-small cell lung cancer, diffuse large B-cell lymphoma, and renal cell carcinoma patients (Frigola et al, 2011; Rossille et al, 2014; Cheng et al, 2015; Wang et al, 2015). We found detectable, but low levels of soluble PD-L1 in all of our patients. Higher baseline levels of soluble PDL1 correlated with nodal status, with higher levels in patients with node-positive disease $(P=0.03)$. Patients with node-negative disease indicated a median serum PD-L1 of $58 \mu \mathrm{g} \mathrm{ml}^{-1}$ at baseline, whereas patients with node-positive disease showed PD-L1 median of $74 \mu \mathrm{g} \mathrm{ml}^{-1}$. Serum PD-L1 levels increased over the course of treatment in $74 \%$ of patients, but this finding did not reach statistical significance $(P=0.16)$.

In a randomly selected subgroup of patients, peripheral blood was collected at baseline (week 1), middle (week 4), end of radiation (week 7), and then again in follow-up at least 1 month following the completion of treatment. Data from the two additional time points confirmed the trends observed in regard to $T$ cells expressing immune checkpoint receptors (Supplementary Figure 1). In many cases, the change observed in the T-cell subset indicated linear increases between the beginning and end time points, and then returned to baseline post treatment.

Of note, there were no significant differences in relative changes in circulating chemokines or immune cell subsets between patients who received concurrent chemotherapy and those treated with radiation alone; however, the generalisability of this finding is limited by the limited number of patients who did not receive concurrent chemotherapy.

T-cell receptor (TCR) diversity. Having identified increases in the percentage of CD8 + T-effector cells, we examined the effects of definitive treatment on TCR diversity in more detail in three patients by performing sequencing of the TCR genes obtained from PBMCs.
In all three patients, treatment resulted in a decrease in the total number of TCR sequences consistent with an overall drop in the absolute number of lymphocytes. However, the percentage of total productive TCR clones remained roughly the same before and after chemoradiation, and the percentage of unique productive sequences actually increased in two of three patients (Supplementary Table 1), suggesting that the overall diversity of productive and relevant $\mathrm{T}$ cells may have actually increased in some patients as a result of treatment. Specifically, there were more new common clones accounting for $>0.01 \%$ of all sequences following treatment as opposed to before in all three patients (Figure $3 \mathrm{~A}$ ). Even when the number of unique clones following treatment was relatively similar to the number of unique clones prior to treatment, as it was in one patient (patient 3), there were striking differences in the frequency with which the most commonly observed TCRs were observed (Figure 3B). Interestingly, this change was accompanied by a 4.8 -fold increase in the ratio of $\mathrm{T}$-effector to $\mathrm{T}$-regulatory cells in this patient.

Changes in antibody responses. We performed exploratory seromic analyses of three patients, one each with tumours in the nasopharynx, oropharynx, and larynx to examine impacts of treatment on humoral immunity. Although overall binding signal tended to decrease over the course of treatment (Supplementary Figure 2), there were increases in the number of antibodies with the strongest signals ( $>6500$ relative fluorescence units) in the two patients who received chemoradiation as opposed to radiation alone. We also identified antibodies targeting particular proteins with greatest signal increase following treatment (Supplementary Table 2). Although the significance of these potential neoantigens is unknown, several immune or tumour-associated proteins were targeted. For example, the patient with nasopharyngeal cancer developed treatment-induced antibodies targeting chemokine 21 (seven-fold), BAFF (six-fold), MAGEH1 (three-fold, a melanomaassociated antigen), and RAB33A (two-fold, Ras-oncogene family). The larynx cancer patient demonstrated increased antibody titres directed against a diverse array of proteins that did include known tumour antigens such as Wilms tumour-associated antigen (WTAP). The oropharynx cancer patient serum demonstrated increased titres of antibodies targeting two immune-related proteins with potential functional implications, CD27 (nine-fold) and IL2RB (two-fold).

Whereas IL2R has an important role in promoting systemic immunity, soluble IL2R is inhibitory and can be produced by tumours (Wang et al, 2000). Therefore, given the increased titres of anti-IL2R antibodies that were detected in one patient, we evaluated soluble IL2R concentrations in the serum of all patients. Interestingly, sIL2R concentrations consistently increased over the course of chemoradiation in our cohort, including the patient who had increased IL2R antibody signal $(P=0.03)$.

\section{DISCUSSION}

We prospectively evaluated circulating immunologic factors in a group of HNSCC patients undergoing definitive RT with or without concurrent chemotherapy to characterise systemic effects of treatment. We measured serum CXCL9, 10, and 16, as well as changes in the proportions of CD8 + T-effector cells, regulatory $\mathrm{T}$ cells, MDSCs, and immune checkpoint-expressing $\mathrm{T}$ cells. We also performed high-throughput sequencing of TCRs and screened for potential anti-tumour antibody responses.

We noted decreased serum CXCL10 concentrations and increased serum CXCL16 following treatment, both of which are consistent with prior in vitro and human studies (Matsumura et al, 2008; Matsumura and Demaria, 2010; Rentoft et al, 2014). CXCL10 may have deleterious effects by stimulating CD133 + tumour stem 
A

Changes in peripheral blood mononuclear cells

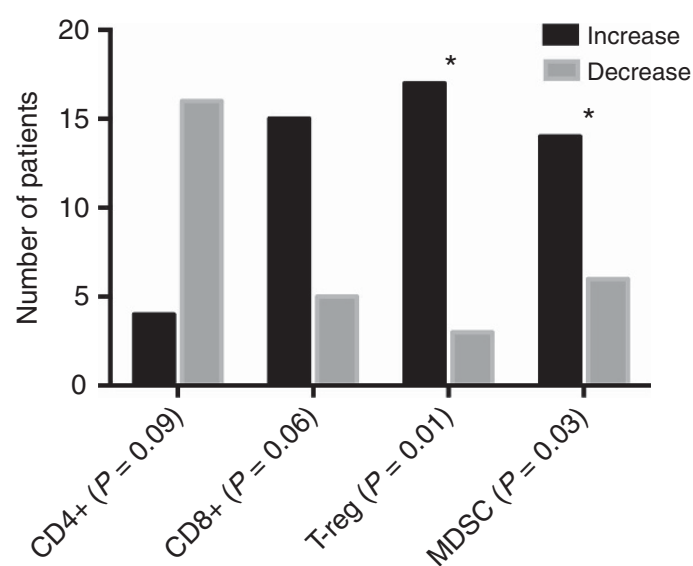

T-cell population

C

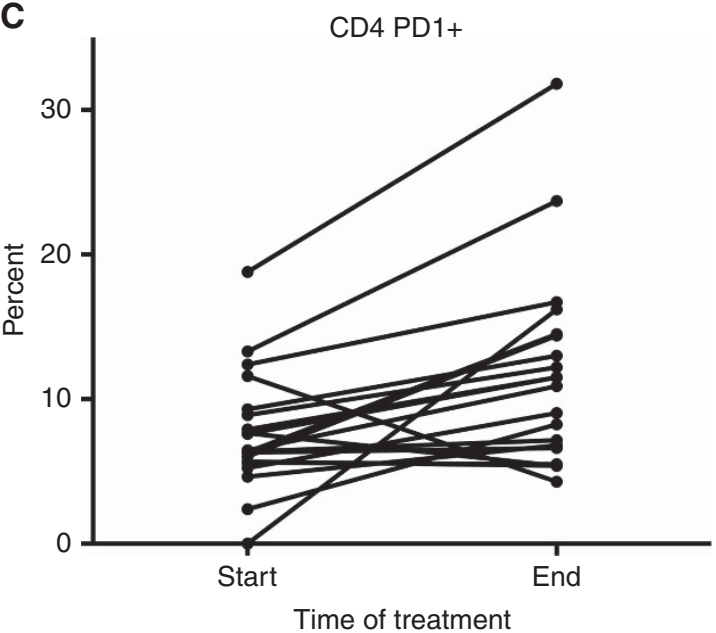

B Changes in T-cell subsets

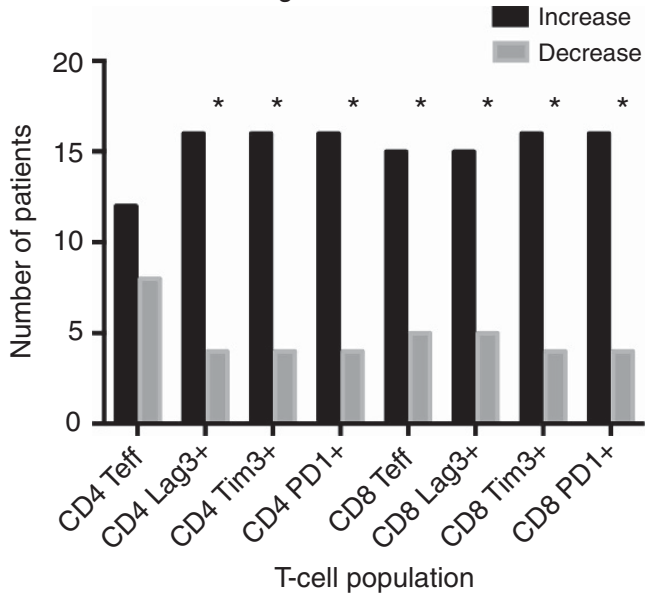

CD8 PD1+

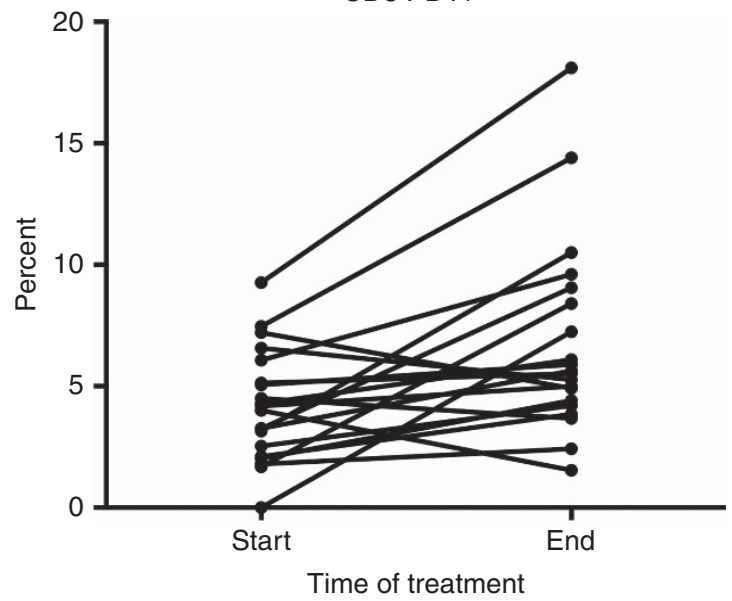

Figure 2. Changes in immune subpopulations over the course of chemoradiation. (A) Changes in T-cell subsets measured as a percentage of PBMCs indicates that total CD4 + T cells decrease and total CD8 T cells increase in most patients, but were not statistically significant $(P=0.09$ and 0.06 , respectively). T-regs increase in most patients $(P=0.01)$, as do MDSCs $(P=0.03)$. (B) When gating by CD4 + or CD8 $+\mathrm{T}$ cells, $\mathrm{CD} 8$ T-effector, CD4 + checkpoint, and CD8 + checkpoint cells increase significantly $(P<0.05)$ in the majority of patients. The changes in CD4 T-effector cells was not significant $(P=0.60)$. (C) The absolute percentage increases in CD4 + and CD8 + PD1 + cells is shown for each patient.
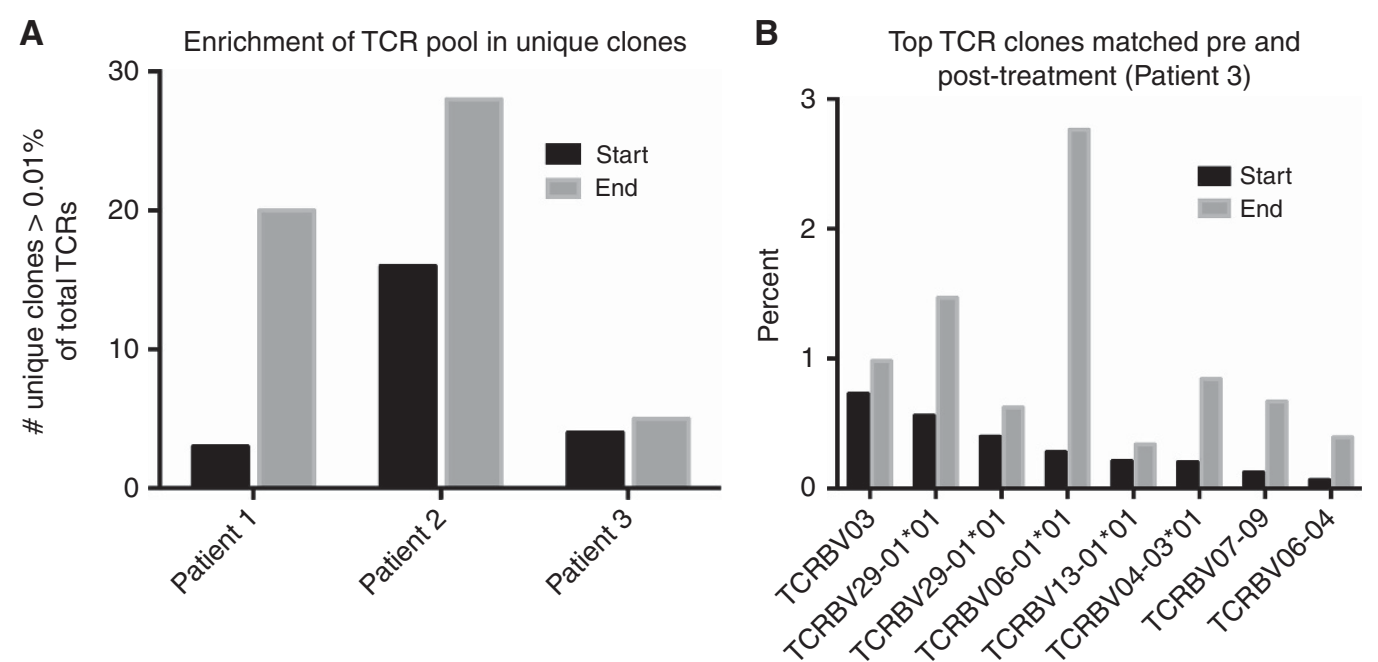

Figure 3. Changes in T-cell receptor diversity over the course of chemoradiation. (A) Unique clones account for a greater percentage of total TCRs post-therapy compared with pre-therapy. (B) In one patient, there is an increase in the percentage of matched top clones post-RT compared with pre-RT. 
cells, or attracting regulatory T cells, and increased CXCL10 levels have been associated with worse cancer-specific outcomes (ZipinRoitman et al, 2007; Lunardi et al, 2015; Ouyang et al, 2015). Conversely, CXCL16 is known to attract tumour-infiltrating T cells or NK cells in lung and colorectal cancers (Hojo et al, 2007; Kee et al, 2013; Hald et al, 2015). High levels of CXCL10 in tumours following radiotherapy have been shown to correlate with poorer overall survival in patients with squamous cell carcinoma of the tongue, suggesting that decreases in CXCL10 might indicate tumour death and a favourable response to therapy (Rentoft et al, 2014). Similarly, irradiation of human and mouse breast tissue (6-12 Gy) in vitro and in mouse models in vivo led to marked increases in CXCL16 secretion that attracted effector $\mathrm{T}$ cells to tumours (Matsumura et al, 2008; Matsumura and Demaria, 2010). Radiation could impact the levels of these cytokines in various ways; tumour death may decrease CXCL10, whereas radiation may stimulate dendritic cells to produce CXCL16 (Piqueras et al, 2006).

Although changes in the tumour microenvironment are likely most relevant to anti-tumour immunity, monitoring changes in circulating immune cells may be a proxy for local anti-tumour immune responses (Twyman-Saint Victor et al, 2015). In addition, evidence of an active systemic immune response may predict for favourable responses following cytotoxic therapy or immunotherapy. For example, increased levels of circulating activated CD4+ ICOS $^{\text {hi }} \mathrm{T}$ cells and increased total lymphocyte counts may correlate with clinical response and overall survival in metastatic melanoma patients treated with immunologic checkpoint blockade using the CTLA-4 inhibitor ipilimumab (Gyorki et al, 2013). Our results indicate that definitive radiation increases circulating CD8+ T-effector cells as a proportion of all CD8 + cells in head and neck cancer patients.

Furthermore, our TCR sequencing and seromics analyses also suggest that radiation can promote anti-tumour immunity. For example, radiation-induced cell death may stimulate antigenspecific adaptive responses via the release of mutated or overexpressed cancer antigens (Prestwich et al, 2008). We demonstrate that chemoradiation can potentially enrich the proportion of top TCR clones in select patients. Although the number of evaluated patients were limited by the cost of seromic profiling, these data suggest that radiation could influence anti-tumour immunity via a humoral response, as has been observed in a previous study of prostate cancer patients undergoing radiation (Nesslinger et al, 2007). Potential antibody targets and neoantigens that we identified in this group of patients include known tumour antigens such as members of the MAGE family as well as other proteins implicated in anti-tumour immunity, such as CD27 and the IL2 receptor. Interestingly, we observed circulating soluble IL2 that tended to increase during treatment. These data may suggest that sIL2R could be an inhibitory signal, but antibodies targeted against sIL2R may block this inhibitory pathway. Previous studies have demonstrated similar pathways involving NKG2D ligands, where soluble versions of the ligands inhibit immune activation, but therapy-induced antibodies targeting these soluble factors circumvent the immune suppression and promote anti-tumour cytotoxicity (Jinushi et al, 2006; Jinushi et al, 2008). Therefore, antibody targeting could benefit a systemic anti-tumour response.

In addition to increases in soluble IL2R, we also observed evidence for other inhibitory effects that may limit the immunestimulating effects of chemoradiation that we observe. Along with the increases in CD8 + T-effector cells, we also found increases in regulatory $\mathrm{T}$ cells and MDSCs. In addition, previous studies have shown that $\mathrm{T}$ cells expressing checkpoint receptors such as PD-1, Tim-3, and Lag-3 may be functionally deficient, or 'exhausted', and unable to effectively participate in anti-tumour immune responses (Wherry and Kurachi, 2015). These results are consistent with prior studies performed by Schuler et al (2013) and Parikh et al (2014), which demonstrate increases in regulatory T cells, MDSCs, and PD-1-expressing $\mathrm{T}$ cells and following head and neck cancer treatment. Intriguingly, recent data also suggest that checkpoint receptor-expressing $\mathrm{T}$ cells may also be enriched for tumour- and mutation-specific clones (Gros et al, 2015); therefore, these increases may also reflect a treatment induced anti-tumour response evidenced by our TCR and seromics data. We found consistent increases in the frequency of these checkpoint receptor-expressing $\mathrm{T}$ cells in the majority of patients. Particularly notable were increases observed in PD-1-expressing cells, which by the end of treatment accounted for more than $10 \%$ and $20 \%$ of total CD8 + and CD $4+$ $\mathrm{T}$ cells in some patients, respectively. Interestingly, there was a corresponding trend for increases in circulating soluble PD-L1, although this did not achieve statistical significance.

Our findings support the notion that conventional treatments such as radiation and chemotherapy have complex effects on systemic anti-tumour immunity, with stimulatory changes balanced by countervailing suppressive mechanisms (Figure 4) that may be dominant under normal circumstances. In regard to radiation, this is consistent with clinical observations, where targeted radiation alone is seldom, if ever, sufficient to generate abscopal, out-of-field immune responses; however ,the same is not true when radiation is administered in combination with immunologic agents (Postow et al, 2012; Golden et al, 2013). Indeed, our findings also support potential mechanisms of synergy between radiation and immunotherapy. Therapies targeting CTLA-4, PD-1, Tim-3, and Lag-3 using blocking antibodies or inhibitors are designed to reinvigorate anti-tumour immunity by impacting functionally deficient T-cell subsets that we here observe to increase following radiation (Ribas, 2012). Furthermore, an abundance of antigenic targets may be associated with a more favourable response to immune checkpoint therapy; our observations regarding the impact of radiation on TCR and antibody responses may be meaningful in this regard (Rizvi et al, 2015; Van Allen et al, 2015).

Our prospective findings are also consistent with preclinical studies and case reports that have observed benefit specifically combining radiation with checkpoint blockade, and suggest further study in starting PD-1 inhibition concurrently with radiation. Radiation resulted in increases in activated $\mathrm{T}$ cells and antibody responses to various tumour-associated antigens in a melanoma patient treated with ipilimumab (Postow et al, 2012), and other case series also demonstrate potential synergistic benefit (Grimaldi et al, 2014; Chandra et al, 2015). A recent preclinical study demonstrating impressive responses following radiation combined with CTLA-4 and PD-1 blockade found that radiation was capable of increasing the diversity and frequency of the most common TCR clones, but T-cell expansion and reversal of T-cell exhaustion only occurred when radiation was coupled to CTLA-4 and PD-1 inhibition (Twyman-Saint Victor et al, 2015). Preliminary studies have also suggested various chemotherapy regimens, such as cisplatin and carboplatin/paclitaxel, in the absence of radiation, may also increase aspects of a CD8 + T-cell anti-tumour response and synergise with immune checkpoint blockade (Lynch et al, 2012; Wei et al, 2013).

The data presented here extend previous findings regarding the effects of chemotherapy and radiation on specific aspects of systemic anti-tumour immunity to head and neck cancer patients, where these results are particularly relevant. Chemoradiation is frequently used in the definitive setting for this disease; however, recurrences are common in patients with high-risk features (Ang et al, 2010). PD-L1 expression has been demonstrated on SCCHN cells, and PD-1 and PD-L1 have single agent activity in the metastatic setting (Lyford-Pike et al, 2013). We also identify soluble PD-L1, Tim-3, and Lag-3 as additional potential mechanisms of immune evasion in SCCHN patients. Thus, acting through some of the mechanisms that we describe, the addition of immune checkpoint blockade could improve results in patients receiving 


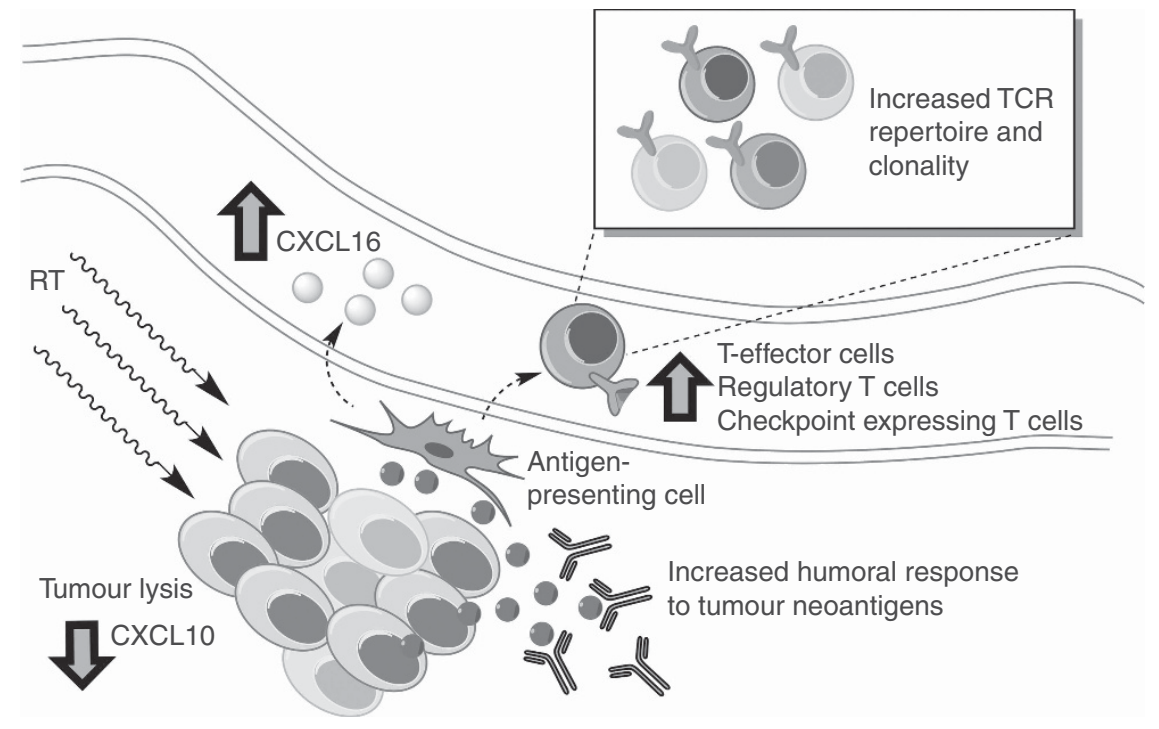

Figure 4. Radiation induced tumour lysis results in decreased tumour CXCL10 secretion, but increased CXCL16 secretion by antigen-presenting cells into circulation to attract $\mathrm{T}$ cells to the tumour microenvironment. In addition, we witness increases in serum T-effector, regulatory T-cell, and checkpoint-expressing T cells, wherein the T cells show increased TCR repertoires and greater clonality. In addition, release of tumourassociated proteins appears to promote an active humoral response against presumed tumour neoantigens.

chemotherapy and radiation in the definitive setting as part of standard of care treatment. In addition, because chemoradiation has systemic immune effects, the addition of this local treatment to immune checkpoint blockade in the setting of metastatic disease could also potentially overcome mechanisms of primary and secondary resistance and increase the number of responding patients.

The extent to which our findings are more generalisable is unknown. Our cohort was relatively homogenous in terms of radiation treatment technique and dose, but there were differences in subsite, stage, and HPV-status among patients. Our results are relatively consistent with effects of radiation observed in preclinical models and human case reports across different types of cancers; therefore, it is plausible that the immunologic effects we observe are fundamentally intertwined with radiation induced cell death for example, as the possible result of activation of the STING pathway or through other mechanisms (Deng et al, 2014b). It is also important to note that the immunologic effects that we observe occurred following conventionally fractionated radiation delivered over a period of 7 weeks as opposed to shorter courses of radiation used in previous case reports or animal models describing synergy between radiation and immunotherapy. Interestingly, fractionated radiation following PD-1 blockade was best at inducing HPV antigen-specific T cells in a mouse model in a recent study (Srivastava et al, 2015). None of our patients were treated with immunotherapies (i.e., PD-1 blockade), but this and other previous studies suggest that the immunologic effects we observe could translate to a treatment approach combining radiation and immunotherapy.

Given that the majority of our patients received concurrent chemotherapy, it is impossible to conclusively determine whether the effects we observe are the result of chemotherapy, radiation, or the combination. The absolute decrease in lymphocytes is likely the result of chemotherapy, as this is often not seen after radiation to the head and neck region alone. In addition, we are unable to determine whether the systemic effects we observe translate to changes that would be observed in the tumour microenvironment. However, preclinical studies and the clinical evaluation of previously irradiated pancreatic and rectal cancer patients have shown that radiation does increase the frequency of tumourinfiltrating CD4 + and CD8 + T cells (Klug et al, 2013; Lim et al, 2014; Teng et al, 2015). Future studies should aim to study differences in immune responses in HPV $+v s \mathrm{HPV}-$ head and neck tumours in larger patient cohorts, as well as correlate whether rising CXCL10 levels predict for clearance of HPV infection. Evaluating tumour specimens could determine whether features such as local PD-1 expression correlates with changes in circulating immune subsets. These studies should also aim to correlate chemokine and immune subset changes with local control and overall survival end points.

In summary, our prospective immunologic profiling suggests that systemic effects of fractionated radiation are relatively reproducible among HNSCC patients. Our findings suggest that radiation-induced effects on the local tumour microenvironment in HNSCC patients may translate into quantifiable immune effects in circulating immune mediators, TCR repertoires, and potential anti-tumour antibody responses. These immune responses are not sufficient to sustain an effective anti-tumour immune response due to matched increases in immunosuppressive mechanisms that feature increases in checkpoint receptor expressing T-cell populations. These results provide insight into the systemic effects of targeted chemoradiation that may contribute to synergy with immunotherapy already observed in animal models and human case reports. Although it appears that radiation alone may potentially inhibit anti-tumour immune responses in various ways, many of these inhibitory effects are now potentially targetable. Immunotherapy, and specifically checkpoint blockade, can potentially tip the balance of stimulating and inhibitory factors resulting from local therapy in favour of a pro-immune state (Formenti and Demaria, 2013; Deng et al, 2014a). Therefore, our results support the continued integration of checkpoint blockade with standard therapies and have the potential to aid in the development of combination treatment regimens incorporating immunotherapy with radiation in SCCHN and other cancers.

\section{ACKNOWLEDGEMENTS}

JDS is supported by the Claudia Adams Barr Program for Innovative Cancer Research and the Joint Center for Radiation Therapy. We acknowledge assistance provided by the Center for Immuno-Oncology at the Dana-Farber Cancer Institute. This work was conducted with support from Harvard Catalyst, The Harvard 
Clinical and Translational Science Center (National Center for Research Resources and the National Center for Advancing Translational Sciences, National Institutes of Health Award UL1 TR001102), and financial contributions from Harvard University and its affiliated academic health-care centres. The content is solely the responsibility of the authors and does not necessarily represent the official views of Harvard Catalyst, Harvard University, and its affiliated academic health-care centres, or the National Institutes of Health.

\section{CONFLICT OF INTEREST}

RIH reports research support from BI, Merck, Bristol-Myers Squibb, ASTRA ZENECA, and CELGENE; and provides consulting for BMS, MERCK, AstraZeneca, and BI. FSH reports grant support from Bristol Myers Squibb, personal fees from Novartis, personal fees and other support from Merck, and other support from Genentech. In addition, FSH reports pending patents related to tumour antigens and uses thereof (patent number 7250291). The remaining authors declare no conflict of interest.

\section{REFERENCES}

Ang KK, Harris J, Wheeler R, Weber R, Rosenthal DI, Nguyen-Tan PF, Westra WH, Chung CH, Jordan RC, Lu C, Kim H, Axelrod R, Silverman CC, Redmond KP, Gillison ML (2010) Human papillomavirus and survival of patients with oropharyngeal cancer. N Engl J Med 363(1): 24-35.

Borghaei H, Paz-Ares L, Horn L, Spigel DR, Steins M, Ready NE, Chow LQ, Vokes EE, Felip E, Holgado E, Barlesi F, Kohlhaufl M, Arrieta O, Burgio MA, Fayette J, Lena H, Poddubskaya E, Gerber DE, Gettinger SN, Rudin CM, Rizvi N, Crino L, Blumenschein Jr. GR, Antonia SJ, Dorange C, Harbison CT, Graf Finckenstein F, Brahmer JR (2015) Nivolumab versus Docetaxel in Advanced Nonsquamous Non-Small-Cell Lung Cancer. N Engl J Med 373(17): 1627-1639.

Brahmer JR, Tykodi SS, Chow LQM, Hwu W-J, Topalian SL, Hwu P, Drake CG, Camacho LH, Kauh J, Odunsi K, Pitot HC, Hamid O, Bhatia S, Martins R, Eaton K, Chen S, Salay TM, Alaparthy S, Grosso JF, Korman AJ, Parker SM, Agrawal S, Goldberg SM, Pardoll DM, Gupta A, Wigginton JM (2012) Safety and activity of anti-PD-L1 antibody in patients with advanced cancer. N Engl J Med 366(26): 2455-2465.

Chandra RA, Wilhite TJ, Balboni TA, Alexander BM, Spektor A, Ott PA, Ng AK, Hodi FS, Schoenfeld JD (2015) A systematic evaluation of abscopal responses following radiotherapy in patients with metastatic melanoma treated with ipilimumab. Oncoimmunology 4(11): e1046028.

Cheng S, Zheng J, Zhu J, Xie C, Zhang X, Han X, Song B, Ma Y, Liu J (2015) $\mathrm{PD}-\mathrm{L} 1$ gene polymorphism and high level of plasma soluble PD-L1 protein may be associated with non-small cell lung cancer. Int J Biol Markers 300(4): e364-e368.

de la Cruz-Merino L, Illescas-Vacas A, Grueso-Lopez A, Barco-Sanchez A, Miguez-Sanchez C. Cancer Immunotherapies Spanish G (2014) Radiation for awakening the dormant immune system, a promising challenge to be explored. Front Immunol 5: 102.

Deng L, Liang H, Burnette B, Beckett M, Darga T, Weichselbaum RR, Fu YX (2014a) Irradiation and anti-PD-L1 treatment synergistically promote antitumor immunity in mice. J Clin Invest 124(2): 687-695.

Deng L, Liang H, Xu M, Yang X, Burnette B, Arina A, Li XD, Mauceri H, Beckett M, Darga T, Huang X, Gajewski TF, Chen ZJ, Fu YX, Weichselbaum RR (2014b) STING-dependent cytosolic DNA sensing promotes radiation-induced type I Interferon-dependent antitumor immunity in immunogenic tumors. Immunity 41(5): 843-852.

Formenti SC, Demaria S (2013) Combining radiotherapy and cancer immunotherapy: a paradigm shift. J Natl Cancer Inst 105(4): 256-265.

Frigola X, Inman BA, Lohse CM, Krco CJ, Cheville JC, Thompson RH, Leibovich B, Blute ML, Dong H, Kwon ED (2011) Identification of a soluble form of $\mathrm{B} 7-\mathrm{H} 1$ that retains immunosuppressive activity and is associated with aggressive renal cell carcinoma. Clin Cancer Res 17(7): 1915-1923.

Golden EB, Demaria S, Schiff PB, Chachoua A, Formenti SC (2013) An abscopal response to radiation and ipilimumab in a patient with metastatic non-small cell lung cancer. Cancer ImmunolRes 1(6): 365-372.
Grimaldi AM, Simeone E, Giannarelli D, Muto P, Falivene S, Borzillo V, Giugliano FM, Sandomenico F, Petrillo A, Curvietto M, Esposito A, Paone M, Palla M, Palmieri G, Caraco C, Ciliberto G, Mozzillo N, Ascierto PA (2014) Abscopal effects of radiotherapy on advanced melanoma patients who progressed after ipilimumab immunotherapy. Oncoimmunology 3: e28780.

Gros A, Tran E, Parkhurst M, Anna P, Ilyas S, Prickett T, Gartner J, Robbins P, Crystal J, Trebska-Mcgowan K, Wudnerlich J, Yang J, Rosenberg S (2015) Selection of circulating PD-1 + lymphocytes from cancer patients enriches for tumor-reactive and mutation-specific lymphocytes. J Immunother Cancer 3(Suppl 2): O2.

Gyorki DE, Callahan M, Wolchok JD, Ariyan CE (2013) The delicate balance of melanoma immunotherapy. Clin Transl Immunology 2(8): e5.

Hald SM, Kiselev Y, Al-Saad S, Richardsen E, Johannessen C, Eilertsen M, Kilvaer TK, Al-Shibli K, Andersen S, Busund LT, Bremnes RM, Donnem T (2015) Prognostic impact of CXCL16 and CXCR6 in non-small cell lung cancer: combined high CXCL16 expression in tumor stroma and cancer cells yields improved survival. BMC Cancer 15: 441 .

Hodi FS, O'Day SJ, McDermott DF, Weber RW, Sosman JA, Haanen JB, Gonzalez R, Robert C, Schadendorf D, Hassel JC, Akerley W, van den Eertwegh AJM, Lutzky J, Lorigan P, Vaubel JM, Linette GP, Hogg D, Ottensmeier CH, Lebbé C, Peschel C, Quirt I, Clark JI, Wolchok JD, Weber JS, Tian J, Yellin MJ, Nichol GM, Hoos A, Urba WJ (2010) Improved survival with ipilimumab in patients with metastatic melanoma. N Engl J Med 363(8): 711-723.

Hojo S, Koizumi K, Tsuneyama K, Arita Y, Cui Z, Shinohara K, Minami T, Hashimoto I, Nakayama T, Sakurai H, Takano Y, Yoshie O, Tsukada K, Saiki I (2007) High-level expression of chemokine CXCL16 by tumor cells correlates with a good prognosis and increased tumor-infiltrating lymphocytes in colorectal cancer. Cancer Res 67(10): 4725-4731.

Jemal A, Simard EP, Dorell C, Noone A-M, Markowitz LE, Kohler B, Eheman C, Saraiya M, Bandi P, Saslow D, Cronin KA, Watson M, Schiffman M, Henley SJ, Schymura MJ, Anderson RN, Yankey D, Edwards BK (2013) Annual Report to the Nation on the Status of Cancer, 1975-2009, featuring the burden and trends in human papillomavirus (HPV)-associated cancers and HPV vaccination coverage levels. J Natl Cancer Inst 105(3): 175-201.

Jinushi M, Hodi FS, Dranoff G (2006) Therapy-induced antibodies to MHC class I chain-related protein A antagonize immune suppression and stimulate antitumor cytotoxicity. Proc Natl Acad Sci USA 103(24): 9190-9195.

Jinushi M, Vanneman M, Munshi NC, Tai YT, Prabhala RH, Ritz J, Neuberg D, Anderson KC, Carrasco DR, Dranoff G (2008) MHC class I chain-related protein $\mathrm{A}$ antibodies and shedding are associated with the progression of multiple myeloma. Proc Natl Acad Sci USA 105(4): $1285-1290$

Kantoff PW, Higano CS, Shore ND, Berger ER, Small EJ, Penson DF, Redfern CH, Ferrari AC, Dreicer R, Sims RB, Xu Y, Frohlich MW, Schellhammer PF. Investigators IS (2010) Sipuleucel-T immunotherapy for castration-resistant prostate cancer. N Engl J Med 363(5): 411-422.

Kee JY, Ito A, Hojo S, Hashimoto I, Igarashi Y, Tsukada K, Irimura T, Shibahara N, Nakayama T, Yoshie O, Sakurai H, Saiki I, Koizumi K (2013) Chemokine CXCL16 suppresses liver metastasis of colorectal cancer via augmentation of tumor-infiltrating natural killer $\mathrm{T}$ cells in a murine model. Oncol Rep 29(3): 975-982.

Klug F, Prakash H, Huber PE, Seibel T, Bender N, Halama N, Pfirschke C, Voss RH, Timke C, Umansky L, Klapproth K, Schakel K, Garbi N, Jager D, Weitz J, Schmitz-Winnenthal H, Hammerling GJ, Beckhove P (2013) Low-dose irradiation programs macrophage differentiation to an iNOS $(+) / \mathrm{M} 1$ phenotype that orchestrates effective $\mathrm{T}$ cell immunotherapy. Cancer Cell 24(5): 589-602.

Levy A, Chargari C, Cheminant M, Simon N, Bourgier C, Deutsch E (2013) Radiation therapy and immunotherapy: implications for a combined cancer treatment. Crit Rev Oncol Hematol 85(3): 278-287.

Lim JY, Gerber SA, Murphy SP, Lord EM (2014) Type I interferons induced by radiation therapy mediate recruitment and effector function of CD8( + ) T cells. Cancer Immunol Immunother 63(3): 259-271.

Lunardi S, Lim SY, Muschel RJ, Brunner TB (2015) IP-10/CXCL10 attracts regulatory T cells: Implication for pancreatic cancer. Oncoimmunology 4(9): e1027473.

Lyford-Pike S, Peng S, Young GD, Taube JM, Westra WH, Akpeng B, Bruno TC, Richmon JD, Wang H, Bishop JA, Chen L, Drake CG, Topalian SL, Pardoll DM, Pai SI (2013) Evidence for a role of the PD-1:PD-L1 pathway in immune resistance of HPV-associated head and neck squamous cell carcinoma. Cancer Res 73(6): 1733-1741. 
Lynch TJ, Bondarenko I, Luft A, Serwatowski P, Barlesi F, Chacko R, Sebastian M, Neal J, Lu H, Cuillerot JM, Reck M (2012) Ipilimumab in combination with paclitaxel and carboplatin as first-line treatment in stage IIIB/IV non-small-cell lung cancer: results from a randomized, doubleblind, multicenter phase II study. J Clin Oncol 30(17): 2046-2054.

Matsumura S, Demaria S (2010) Up-regulation of the pro-inflammatory chemokine CXCL16 is a common response of tumor cells to ionizing radiation. Radiat Res 173(4): 418-425.

Matsumura S, Wang B, Kawashima N, Braunstein S, Badura M, Cameron TO, Babb JS, Schneider RJ, Formenti SC, Dustin ML, Demaria S (2008) Radiation-induced CXCL16 release by breast cancer cells attracts effector T cells. J Immunol 181(5): 3099-3107.

Motzer RJ, Escudier B, McDermott DF, George S, Hammers HJ, Srinivas S, Tykodi SS, Sosman JA, Procopio G, Plimack ER, Castellano D, Choueiri TK, Gurney H, Donskov F, Bono P, Wagstaff J, Gauler TC, Ueda T, Tomita Y, Schutz FA, Kollmannsberger C, Larkin J, Ravaud A, Simon JS, Xu LA, Waxman IM, Sharma P, CheckMate I (2015) Nivolumab versus everolimus in advanced renal-cell carcinoma. N Engl J Med 373(19): 1803-1813.

Nesslinger NJ, Sahota RA, Stone B, Johnson K, Chima N, King C, Rasmussen D, Bishop D, Rennie PS, Gleave M, Blood P, Pai H, Ludgate C, Nelson BH (2007) Standard treatments induce antigen-specific immune responses in prostate cancer. Clin Cancer Res 13(5): 1493-1502.

Ouyang Y, Liu K, Hao M, Zheng R, Zhang C, Wu Y, Zhang X, Li N, Zheng J, Chen D (2015) Radiofrequency ablation-increased CXCL10 is associated with earlier recurrence of hepatocellular carcinoma by promoting stemness. Tumour Biol 373(3): 3697-3704.

Parikh F, Duluc D, Imai N, Clark A, Misiukiewicz K, Bonomi M, Gupta V, Patsias A, Parides M, Demicco EG, Zhang DY, Kim-Schulze S, Kao J, Gnjatic S, Oh S, Posner MR, Sikora AG (2014) Chemoradiotherapyinduced upregulation of PD-1 antagonizes immunity to HPV-related oropharyngeal cancer. Cancer Res 74(24): 7205-7216.

Piqueras B, Connolly J, Freitas H, Palucka AK, Banchereau J (2006) Upon viral exposure, myeloid and plasmacytoid dendritic cells produce 3 waves of distinct chemokines to recruit immune effectors. Blood 107(7): 2613-2618.

Postow MA, Callahan MK, Barker CA, Yamada Y, Yuan J, Kitano S, Mu Z, Rasalan T, Adamow M, Ritter E, Sedrak C, Jungbluth AA, Chua R, Yang AS, Roman RA, Rosner S, Benson B, Allison JP, Lesokhin AM, Gnjatic S, Wolchok JD (2012) Immunologic correlates of the abscopal effect in a patient with melanoma. $N$ Engl J Med 366(10): 925-931.

Prestwich RJ, Errington F, Hatfield P, Merrick AE, Ilett EJ, Selby PJ, Melcher AA (2008) The immune system-is it relevant to cancer development, progression and treatment? Clin Oncol 20(2): 101-112.

Rentoft M, Coates PJ, Loljung L, Wilms T, Laurell G, Nylander K (2014) Expression of CXCL10 is associated with response to radiotherapy and overall survival in squamous cell carcinoma of the tongue. Tumour Biol 35(5): 4191-4198.

Ribas A (2012) Tumor immunotherapy directed at PD-1. N Engl J Med 366(26): 2517-2519.

Rizvi NA, Hellmann MD, Snyder A, Kvistborg P, Makarov V, Havel JJ, Lee W, Yuan J, Wong P, Ho TS, Miller ML, Rekhtman N, Moreira AL, Ibrahim F, Bruggeman C, Gasmi B, Zappasodi R, Maeda Y, Sander C, Garon EB, Merghoub T, Wolchok JD, Schumacher TN, Chan TA (2015) Cancer immunology. Mutational landscape determines sensitivity to PD-1 blockade in non-small cell lung cancer. Science 348(6230): 124-128.

Robert C, Thomas L, Bondarenko I, O'Day S, Weber J, Garbe C, Lebbe C, Baurain J-F, Testori A, Grob J-J, Davidson N, Richards J, Maio M, Hauschild A, Miller WH, Gascon P, Lotem M, Harmankaya K, Ibrahim R, Francis S, Chen T-T, Humphrey R, Hoos A, Wolchok JD (2011) Ipilimumab plus dacarbazine for previously untreated metastatic melanoma. N Engl J Med 364(26): 2517-2526.

Rossille D, Gressier M, Damotte D, Maucort-Boulch D, Pangault C, Semana G, Le Gouill S, Haioun C, Tarte K, Lamy T, Milpied N, Fest T. Groupe Ouest-Est des Leucemies et Autres Maladies du S. Groupe Ouest-Est des Leucemies et Autres Maladies du S (2014) High level of soluble programmed cell death ligand 1 in blood impacts overall survival in aggressive diffuse large B-cell lymphoma: results from a French multicenter clinical trial. Leukemia 28(12): 2367-2375.

Schoenfeld JD (2015) Immunity in head and neck cancer. Cancer Immunol Res 3(1): 12-17.
Schuler PJ, Harasymczuk M, Schilling B, Saze Z, Strauss L, Lang S, Johnson JT, Whiteside TL (2013) Effects of adjuvant chemoradiotherapy on the frequency and function of regulatory $\mathrm{T}$ cells in patients with head and neck cancer. Clin Cancer Res 19(23): 6585-6596.

Segal NH, Antonia SJ, Brahmer JR, Maio M, Blake-Haskins A, Li X, Vasselli J, Ibrahim RA, Lutzky J, Khleif S (2014) Preliminary data from a multi-arm expansion study of MEDI4736, an anti-PD-L1 antibody. J Clin Oncol 32(15): 3002.

Seiwert TY, Burtness B, Weiss J, Gluck I, Eder JP, Pai SI, Dolled-Filhart M, Emancipator K, Pathiraja K, Gause C, Iannone R, Brown H, Houp J, Cheng JD, Chow LQM (2014) A phase Ib study of MK-3475 in patients with human papillomavirus (HPV)-associated and non-HPV-associated head and neck (H/N) cancer. J Clin Oncol 32(15): 6011.

Sridharan V, Schoenfeld JD (2015) Immune effects of targeted radiation therapy for cancer. Discov Med 19(104): 219-228.

Srivastava R, Clump D, Ferris R (2015) Anti-PD-1 mAb pre-radiotherapy (RT) loading dose and fractionated RT induce better tumor-specific immunity and tumor shrinkage than sequential administration in an HPV + head and neck cancer model. J Immunother Cancer 3(Suppl 2): P314.

Teng F, Mu D, Meng X, Kong L, Zhu H, Liu S, Zhang J, Yu J (2015) Tumor infiltrating lymphocytes (TILs) before and after neoadjuvant chemoradiotherapy and its clinical utility for rectal cancer. Am J Cancer Res 5(6): 2064-2074.

Topalian SL, Hodi FS, Brahmer JR, Gettinger SN, Smith DC, McDermott DF, Powderly JD, Carvajal RD, Sosman JA, Atkins MB, Leming PD, Spigel DR, Antonia SJ, Horn L, Drake CG, Pardoll DM, Chen L, Sharfman WH, Anders RA, Taube JM, McMiller TL, Xu H, Korman AJ, Jure-Kunkel M, Agrawal S, McDonald D, Kollia GD, Gupta A, Wigginton JM, Sznol M (2012) Safety, activity, and immune correlates of anti-PD-1 antibody in cancer. N Engl J Med 366(26): 2443-2454.

Twyman-Saint Victor C, Rech AJ, Maity A, Rengan R, Pauken KE, Stelekati E, Benci JL, Xu B, Dada H, Odorizzi PM, Herati RS, Mansfield KD, Patsch D, Amaravadi RK, Schuchter LM, Ishwaran H, Mick R, Pryma DA, Xu X, Feldman MD, Gangadhar TC, Hahn SM, Wherry EJ, Vonderheide RH, Minn AJ (2015) Radiation and dual checkpoint blockade activate non-redundant immune mechanisms in cancer. Nature 520(7547): 373-377.

Van Allen EM, Miao D, Schilling B, Shukla SA, Blank C, Zimmer L, Sucker A, Hillen U, Foppen MH, Goldinger SM, Utikal J, Hassel JC, Weide B, Kaehler KC, Loquai C, Mohr P, Gutzmer R, Dummer R, Gabriel S, Wu CJ, Schadendorf D, Garraway LA (2015) Genomic correlates of response to CTLA-4 blockade in metastatic melanoma. Science 350(6257): 207-211.

Wang L, Wang H, Chen H, Wang WD, Chen XQ, Geng QR, Xia ZJ, Lu Y (2015) Serum levels of soluble programmed death ligand 1 predict treatment response and progression free survival in multiple myeloma. Oncotarget 6(38): 41228-41236.

Wang LS, Chow KC, Li WY, Liu CC, Wu YC, Huang MH (2000) Clinical significance of serum soluble interleukin 2 receptor-alpha in esophageal squamous cell carcinoma. Clin Cancer Res 6(4): 1445-1451.

Wei H, Zhao L, Li W, Fan K, Qian W, Hou S, Wang H, Dai M, Hellstrom I, Hellstrom KE, Guo Y (2013) Combinatorial PD-1 blockade and CD137 activation has therapeutic efficacy in murine cancer models and synergizes with cisplatin. PloS One 8(12): e84927.

Wherry EJ, Kurachi M (2015) Molecular and cellular insights into T cell exhaustion. Nat Rev Immunol 15(8): 486-499.

Wolchok JD, Chan TA (2014) Cancer: antitumour immunity gets a boost. Nature 515(7528): 496-498.

Zipin-Roitman A, Meshel T, Sagi-Assif O, Shalmon B, Avivi C, Pfeffer RM, Witz IP, Ben-Baruch A (2007) CXCL10 promotes invasion-related properties in human colorectal carcinoma cells. Cancer Res 67(7): 3396-3405.

This work is published under the standard license to publish agreement. After 12 months the work will become freely available and the license terms will switch to a Creative Commons AttributionNonCommercial-Share Alike 4.0 Unported License.

Supplementary Information accompanies this paper on British Journal of Cancer website (http://www.nature.com/bjc) 